\title{
FICTIONS IN THE THOUGHT OF SIR JOHN SALMOND
}

\author{
Alex Frame *
}

A Lecture delivered for the Stout Centre's "Eminent Victorians" Centennial Series in the Council Chamber, Hunter Building at Victoria University on 31 March 1999. The Stout Centre intends to publish the series later in the year.

\section{INTRODUCTION}

Two images will provide the background for the study I would like to make tonight of our "eminent Victorian", our intellectual tupuna, Sir John Salmond, who lived between 1862 and 1924, taught law at this College from 1906 to 1907, and thereafter served our country in high legal office until his death.

The first shows the founding Professors of our Law Faculty - Salmond and Maclaurin - together with Sir Robert Stout and other teachers and leaders of the then College, on the steps of this building at its opening on 30 March $1906 .{ }^{1}$ Here then is Professor Salmond at age 44, freshly arrived from the University of Adelaide whence enticed - in breach of contract - by Sir Robert Stout. He is already the author of Jurisprudence: or the Theory of the Law, ${ }^{2}$ a work praised in the Harvard Law Review as "the work of a bold and original

* Director of the New Zealand Institute of Public Law, Faculty of Law, Victoria University of Wellington.

1 The image was published in the New Zealand Mail of 11 April 1906 with the caption "Group taken at Victoria College". Sir Robert Stout (Chancellor of the University), Members of the College Council and Professorial Board. Stout is top-hatted in the centre-front, the other top hat in the front is Sir Francis Bell. Salmond and Maclaurin are the central figures three rows back. I am most grateful to the author of the forthcoming history of the University, Ms Rachel Barrowman, for assistance with identification of other figures in the photograph: Maurice Richmond (another teacher of law, and another mathematician/lawyer! Richmond, a latecomer to law, had won the de Rothschild Exhibition for Pure Mathematics at University College, London, in 1880 - just before Salmond's time there), Professors Mackenzie, Rankine Brown, Kirk, Easterfield, and the Registrar, C P Powles.

2 (Stevens \& Haynes, London, 1902). 
thinker and forceful writer", 3 and by the pre-eminent legal historian Maitland as a "liberal and liberating"4 text suitable to the needs of Maitland's students. Next year, he will publish The Law of Torts - judged by Harvard University in 1911 to be the best law book written in the English language in the preceding five years. ${ }^{5}$ Think of the competition, put aside all doubt that we have here a great writer, and wonder why no example of, or reference to, his work appears in recently published surveys of New Zealand literature. ${ }^{6}$

The second image presents Salmond on the steps of Washington Railway Station, on the morning of 12 November 1921, with other members of the British Empire Delegation on arrival at the Washington Disarmament Conference. ${ }^{7}$ Now, he has been a high-level adviser to government for a decade as Solicitor-General, and most recently has taken his place on Chief Justice Sir Robert Stout's Supreme Court. His appointment as New Zealand delegate to Washington reflects the confidence of political leaders earned in times of tumult and peril for the state from the near civil war of 1913 through the desperate and brutal days of the Great War, to the constitutional and territorial manoeuvrings of the Peace. He will be busy today: placing the New Zealand wreath at Washington's war memorial and still finding time to give an interview to a journalist which will get him into trouble with the Canadian delegate, Sir Robert Borden. On the left hand of the tall figure of the Delegation leader, Lord Balfour, is US Secretary of State, Charles Evans Hughes: later this day he proposes to the Conference at its opening the famous ratio of battleships and defences between the major powers - hindsight tells us that the acceptance of this at the Conference gave the balance of military advantage in the Western Pacific to Japan.

3 Book Note "Jurisprudence or the Theory of Law" [1903] 16 Harv L Rev 315.

4 H A L Fisher (ed) The Collected Papers of Fredrick William Maitland, Vol 3 (Cambridge University Press, Cambridge, 1911) 419.

5 The Law ofTorts (Stevens \& Haynes, London, 1907).

6 Neither Roger Robinson and Nelson Wattie (eds) The Oxford Companion to New Zealand Literature, (Oxford University Press, 1998), nor Terry Sturm (ed) The Oxford History of New Zealand Literature in English (2 ed, Oxford University Press, 1998), make mention of Salmond's contributions.

7 This image appeared in New Zealand Freelance of 5 April 1922 with the caption 'British and American Delegates - an Interesting Group'. In front: Lord Lee (First Lord of the British Admiralty), Sir John Salmond (New Zealand's representative), General the Earl of Caven (a British delegate), Sir A J Balfour (now Earl Balfour) enjoys a little joke sprung on him by Mr Hughes (United States Secretary of State), Senator Pearce (Australian Minister of Defence). Standing at back, on left hand side: General Pershing (USA) and Sir Maurice Hankey (Secretary to the British Cabinet). The American host, Hughes, had a truly stellar judicial career at both domestic and international levels. 
The first image reminds us of the connection between Salmond and this building and College in their earliest years. The second recalls that Salmond was a man of two worlds of abstract ideas but also of government in action; of philosophy but also of statecraft and realpolitik. Sir Ivor Richardson has pictured Salmond as: ${ }^{8}$

A man of determination and action, a prodigious worker who, at the same time, was interested

in exploring concepts and analysing ideas.

We should not forget Salmond's sense of humour either. It was Froggie de la Mare who recalled that at the first graduates' dinner, Professor Salmond proposed a toast to "The Affiliated Colleges" and gave "the wittiest of speeches" on "the strangest affiliation case in legal history". ${ }^{9}$

Both photographs are also connected with my theme for this evening - the place of fictions in the thought of Sir John Salmond.

\section{FICTIONS - BEYOND THE LIMITS OF FACT}

Salmond's proximity to the remarkable lawyer/physicist Richard Cockburn Maclaurin on the steps of this building in 1906 provides our first connection. Maclaurin, on whom Sir Kenneth Keith, our distinguished colleague, will speak here later in the year, understood well the epistemological status - and the utility - of the fiction. Maclaurin's thesis on "The Theory of Light", published in Cambridge in 1908, contains this statement: 10

We postulate the existence of the ether...at the same time we need not concern ourselves with the "reality" of the ether, nor take the unphilosophical step of pronouncing it to be real merely because it is a conception that is convenient for our special purpose

8 Sir Ivor Richardson, President of the New Zealand Court of Appeal, very generously spoke at the launch in this building, on 12 October 1995, of my biography Salmond: Southern Jurist, (Victoria University Press, Wellington, 1995).

9 F A de la Mare, "A Knight's Progress" in Ernest Beaglehole The University and the Community: Essays in Honour of Thomas Alexander Hunter (Victoria University College, Wellington,1946) 12. At the same dinner, Professor von Zedlitz is reported as making 'a frontal attack' on the Chancellor, Sir Robert Stout:

we held our breath as this Oxford graduate hurled the whole armoury of his wit, all the resources of his philosophy, and all his capacity for rhetorical irony at the white beard of our principal guest.

10 The Theory of Light: A Treatise on Physical Optics, (Cambridge University Press, Cambridge, 1908). For brief discussion, see Salmond: Southern Jurist above $\mathrm{n} 8,72$ at $\mathrm{n} 2$. The quotations are from pages 10 and 4 of Maclaurin. 
(1999) 30 VUWLR 
and also this story of the artist who: ${ }^{11}$

after devoting his life to portraiture, declared that the only real thing was paint. (This approach) takes certain qualities of things, arbitrarily abstracts something, and then declares the abstraction to be real and all that is real. This, of course, is to take a ghost for reality, and there is actually a school so frightened by the ghost as to worship it.

Lon Fuller observes that "the fiction finds its most pervasive application in two subjects that seem in other respects at opposite poles from one another: physics and jurisprudence". ${ }^{12}$ The similarity between Maclaurin's approach and that of Salmond with regard to the principles of political economy, or to legal personality, is evident: ${ }^{13}$

The principles of political economy are obtained by the elimination of every motive save the desire for wealth, but we do not apply them blindfold to individual cases without first taking account of the possibly disturbing influence of the eliminated elements.

or again: ${ }^{14}$

A legal person is any subject-matter to which the law attributes a merely legal or fictitious personality. This extension, for good and sufficient reasons, of the conception of personality beyond the limits of fact - this recognition of persons who are not men - is one of the most noteworthy feats of the legal imagination.

As to the relationship between the fiction and "truth", Salmond had stated as early as 1893 his view that the object of the fiction was: ${ }^{15}$

not to establish the truth, but to subvert it in the interests of justice.

Maclaurin and Salmond are thus epistemological brothers-in-law: they understand the nature, the utilities, and the dangers of the fiction, matters to which I would now like to turn.

11 Maclaurin, above $\mathrm{n} 10$.

12 Lon Fuller, Legal Fictions (Stanford University Press, 1967). Fuller suggests that it is the urge towards comprehensive system which provides the common interest.

13 Salmond, Jurisprudence, (7 ed, Stevens \& Haynes, London, 1924) 45-46. It is convenient to draw throughout this paper on the 7th edition of the work, published in 1924, being the last for which Salmond was personally responsible.

14 Salmond, Jurisprudence, 7 ed, above n 13,336

15 Salmond, The First Principles of Jurisprudence, (Steven and Haynes, London, 1893) 85. 


\section{THE NATURE, UTILITY, AND DANGERS OF FICTIONS}

Two writers stand out as our guides to the world of "As if": the American jurist Lon Fuller, ${ }^{16}$ and the German philosopher Hans Vaihinger. ${ }^{17}$ Both thinkers developed a strong interest in the device whereby we deliberately and openly distort or falsify what we know, or believe, to be true. I emphasise that the device differs from the mere lie (and also from simple error) in that it contains, explicitly or implicitly, the admission of its own contradictory nature. In fact, as Fuller's masterly exposition shows, there are many kinds of fiction, and the motives for them also differ widely. Ranging from the heuristic fiction - such as Maclaurin's "ether" - which serves as a tool of inquiry and understanding, to the more prosaic prescriptive fiction by which the law may insist that red be treated as if it were blue.

As to the utility of the fiction, it seems generally agreed that the device is facilitative in permitting escape, if only provisionally, from the tyranny of apparent fact. Vaihinger observes that it provides "an instrument for finding our way about more easily in the world", and comments that: ${ }^{18}$

although in thinking we make use of a falsified reality, the practical result still proves to be right.

Sir Kenneth Keith has reminded us in his recent Harkness Lecture ${ }^{19}$ of T H Huxley's salutary dictum that "many a pretty theory has been slain by ugly facts", but here is a weapon which turns the tables - we might almost say that "many an ugly fact has been slain by a pretty fiction". In the world of "as if", it is facts which are on the run - subject to a warning.

There is a Buddhist story - which I think Sir John Salmond would have enjoyed. The Master exhorted his students to pay no attention to the illusions and distractions of the

16 Fuller's ideas on Fictions first appeared in 1930 and 1931 in 25 Illinois L Rev but are now conveniently brought together in Legal Fictions, (Stanford University Press, 1967).

17 Hans Vaihinger (1852-1933) started his thesis in 1876, and published Die Philosophie das Als-Obs (The Philosophy of As-If) in Berlin in 1911. The work was first published in English translation (by C K Ogden) by Kegan Paul in 1924. In a note in the Encyclopedia of Philosophy, Vol 8, 224, Rollo Handy states:

The English translation by CK Ogden...was made from the sixth German edition, specially revised by Vaihinger for the English-speaking world...

An interesting entry in Katherine Mansfield's Notebook in 1921 in relation to Vaihinger's book is discussed in Salmond: Southern Jurist, above n 8, 32 and n 36.

18 Vaihinger, above $\mathrm{n} 17,159$.

19 Rt Hon K J Keith "The Impact of International Law on New Zealand Law" (1998) 6 Waikato LR 1. 
sensory world, but to go about their lives listening only for the voice of God. Later, a bruised and dishevelled student came breathless to the Master complaining that he had been walking along the road intently following the Master's instructions, paying no attention whatever to the mere forms of the world, totally alert for the voice of God, and suddenly he was run over by an elephant. "What did you think you were doing?", the Master asked impatiently, "that was the voice of God!".

In reality, we might be safer to say, with Lon Fuller, that facts and theories are in an interdependent and dynamic relationship. Fuller quotes Morris Cohen: ${ }^{20}$

...facts are not so rigid and theories not so flexible; and when the two do not fit, the process of adaptation is a bilateral one. When new facts come up inconsistent with previous theories, we do not give up the latter, but modify both the facts and the theory by the introduction of new distinctions or of hypothetical elements.

The danger of fictions is that when the moment of truth arrives - when the Faustian pact which had released us from the tyranny of fact falls due - we have forgotten the provisional and suspensory nature of the device. Intoxicated by the freedom so marvellously discovered, we are reluctant to abandon the clarity which it has appeared to create. As Fuller puts it, following Vaihinger: ${ }^{21}$

these constructs must be used as instruments of thought only; we must treat them as servants to be discharged as soon as they have fulfilled their functions. They are foreign elements which may be inserted into the equation provisionally to render computation simpler, but which must be dropped from the final reckoning.

Common lawyers understand the point well in respect of legal fictions, and a great eighteenth century judge observed: ${ }^{22}$

But fictions of law hold only in respect to the ends and purposes for which they were invented; when they are urged to an intent and purpose not within the reason and policy of the fiction, the other party may show the truth.

Vaihinger distinguishes three kinds of statement - each with its own epistemological status: ${ }^{23}$

20 Fuller, Legal Fictions, above n 11, 133-134. The quotation is from Morris Cohen. "The Place of Logic in the Law" (1916) 29 Harv L REV 622, 626.

21 Fuller, Legal Fictions, above n 12, 121

22 Lord Mansfield CJ in Morris v Pugh (1761) 3 Burr 1242, 1243, quoted in Fuller at 51, n 4.

23 Hans Vaihinger, The Philosophy of As If , above n 12, 124 and elsewhere. 
1. The Fiction: a statement known and admitted to be at variance with the real world, but found provisionally useful for a variety of reasons.

2. The Hypothesis: a statement aspiring faithfully to reflect the real world, but purporting to do so only provisionally and subject to modification if testing reveals it to be deficient.

3. The Dogma: a statement so evidently expressing the truth of the real world as to reside beyond further inquiry or discussion.

Vaihinger points out that ideas have a habit of journeying from status to status without it being noticed, calling this phenomenon the "law of ideational shift". Thus, for example, the modern tendency has been to treat some Biblical accounts formerly viewed as dogma as being in the nature of hypothesis, or even instructive fiction. Conversely, Adam Smith's conscious fiction as to motive and political economy has come to be seen as hypothesis or even, in the eyes of some, as dogma. ${ }^{24}$ Similarly, the fiction that civil servants sell goods to their Ministers comes to be seen as relating in some way to reality and so to entail consequences for the production and marketing of the "goods" and the organisation of the civil service. Policies come to be seen as good because faithful to the "market model" - forgetting that the "market model" is a fiction. Policies may indeed be good, but assuredly not because of fidelity to a fiction. As Vaihinger characterises Adam Smith's simplification:

great value as a fiction, positively ruinous as a hypothesis or dogma.

The danger is thus identified by Vaihinger: ${ }^{25}$

The greatest and most important human errors originate through thought-processes being

taken for copies of reality itself

\section{LEGISLATIVE FICTIONS}

Those two little words - "as if" - are dynamite in the hands of the legislator. The world can be refashioned in accordance with the legislator's desires. Salmond as master law drafter was well aware of the utility of treating that which is not true as if it were true, and that which is true as if it were not true. Sir Kenneth Keith has run a computer search on the frequency of the words "as if" in the body of New Zealand statute law and discovers the total to be 7756 !

24 Vaihinger uses this example, cf Salmond above, pointing out that Adam Smith treats human action and the conduct of business as if their driving force lay in but one single factor - egoism. By cutting away all other motives - goodwill, habit, etc. - it is possible to deduce the relations of trade and commerce. Vaihinger, above $\mathrm{n} 17,20$.

25 Vaihinger, above $n 17,8$. 
Look no further than Salmond's Land and Income Assessment Act 1907, in which shareholders of a land-owning company are liable as if they were owners of the company's land; equitable owners are liable as if they were legal owners; trustees are liable as if beneficially entitled, and so on. Or his Death Duties Act 1909, in which a ship overseas is treated as if it were property in New Zealand, and shares held overseas in a New Zealand company are treated as if they were property in New Zealand.

Incidentally, it is no accident that my examples come from areas of law which create the temptation to use legal forms to disguise substance and so, by creating legal facts, to avoid undesired consequences - typically taxation. ${ }^{26} \mathrm{~A}$ useful weapon in the armoury of the legislator is to head off these disguises by requiring the legal facts so created to be treated as if they were identical to the legal facts from which it had been sought to escape. Like so many Barbie Dolls, citizens can be kitted out with intentions never formed, transactions never entered into, and benefits never enjoyed. Ships on the high seas can be transported miraculously to Wellington harbour. Truly, if poets are the unacknowledged legislators of the world, may it not be equally true that the legislator armed with the fiction is an unacknowledged poet of the world, before whom the real world is infinitely malleable putty?

I should note here two dangers of the fiction as a device for preventing the exploitation of legal forms to frustrate the intent of legal policy. First, use of the device strengthens the legitimacy and likely success of such exploitation in respect of those legal forms as are not specifically targeted - thus, if legal facts A, B and C are specifically treated as if they were legal fact $T$ (Taxable), then by implication legal fact $X$, which has not been designated, is not to be so treated, however artificial its existence may appear to be. Secondly, an ever-widening net of fictions may end in frustration and a despairing lunge towards legislation of the Danzig Decree type promulgated by the Nazi regime in the 1930s:

Any person who commits an act which this law deems to be punishable or which is deserving of penalty according to the fundamental conceptions of a penal law and sound popular feeling, shall be punished. If there is no penal law directly covering an act, it shall be punished under the law of which the fundamental conception applies most nearly to the said act.

26 Of the 7756 "as ifs" on the New Zealand statute book, 325 are in the Income Tax Act 1994. For a discussion of the techniques available to control tax avoidance, see John Prebble, "Should Tax Legislation be written from a Principles and Purpose Point of View or a Precise and Detailed Point of View?" [1998] British Tax Rev 112. The concept of 'ectopia', which Professor Prebble has developed to explain the problems of tax law, would appear to be essentially the same as that of the fiction understood sufficiently widely. 


\section{CONSTITUTIONAL FICTIONS}

Here is a second type of legislative fiction - this time at the constitutional level. Salmond's Samoa Constitution Order 1920 declared that: ${ }^{27}$

The Executive government of Samoa is hereby declared to be vested in His Majesty the King in the same manner as if the territory was part of His Majesty's dominions.

Note the brevity with which Salmond as draftsman is able to empower the executive government of Samoa, whilst avoiding the question of the exact constitutional status of Samoa under the League of Nations Mandate. Indeed, if the declaration had anything to say about that status it must surely be that Samoa was not part of His Majesty's dominions! But the subsequent history of the fiction with respect to Samoa shows one of the dangers of the device - that if used too boldly, it may come to lose its fictive aspect. "As if" may, in the eyes of interpreters, come to mean "is". 28

I had promised to return to our second image in connection with fictions. Salmond on the steps of Washington Railway Station in 1921 - about to give an interview to a reporter from the Evening Star. That journal carried a story that night headed "New Zealand Firm for United Empire" and quoted Sir John Salmond as stating that the Dominions had no international existence and recognition separate from that of the British Empire, whatever conventional practices might properly develop to ensure dominion representation within that overarching unity. Other Dominion representatives on the British Empire Delegation were incensed - in particular, the Canadian representative, Sir Robert Borden. Sir Maurice Hankey, the "man of secrets" as his biographer titled a volume on the long-serving British Cabinet Secretary, needed all his skills to placate Borden's resentment of this challenge to Canadian doctrine - and practice - affirming its international status. ${ }^{29}$ How then did Salmond explain the apparent concession in the Treaty of Versailles and at the League of Nations of the independent position of the Dominions? Again, the fiction is made to serve: ${ }^{30}$

27 The background to the League of Nations Mandate, the New Zealand response, and Sir John Salmond's involvement as Solicitor-General and draftsman is treated in Salmond: Southern Jurist, above $n$ 8, 189-197.

28 I have in mind here, of course, the Privy Council's decision in Lesa v Attorney-General [1982] 1 NZLR 165.

29 The background is dealt with in some detail in Salmond: Southern Jurist, above n 8, 202-210

30 These observations are found in Sir John Salmond's subsequent report to the New Zealand Parliament [1922] AJHR 1-15, 15. 
By the special and peculiar organization of that body, self-governing colonies are admitted in their own right as if they were independent states.....they are entitled by express agreement to be treated as if they were independent...

Salmond's fiction saves both the unity of the Empire and the practical, de facto autonomy of the Dominions. But what is the difference between being "as if" independent, and being "really" independent? Not very much, and here Saleilles' dictum reminds us of another limit on the range of the fiction: ${ }^{31}$

Indeed, what is a fiction which becomes indispensable if not a reality?

\section{CORPORATE PERSONALITY - FICTION AND REALIST THEORIES}

It was Sir John Salmond's conception of the nature of "corporate personality" however (and his supposed view of this as fiction) that sparked a debate which I should now note. The issue may best emerge if we consider the thing we call Victoria College - latterly, Victoria University. If we seek its true date of birth we may find ourselves looking at the Victoria College Act 1897 and the words in section 3:

The Council of the College, its professors and lecturers, and the graduates and undergraduates of the New Zealand University whose names are on its books, are hereby constituted a body politic and corporate under the style of "The Victoria College" by which style that corporation shall have perpetual succession and a common seal.

The Act came into force on the date it received the Royal Assent - 22 December 1897.

From that date, therefore, our "thing" had legal recognition, awaiting only the creation of its constituent elements (the Council, Professorial Board, and so on) to spring forth in the pursuit of knowledge.

Victoria University's modern legal identity arises from the Victoria University of Wellington Act 1961, which continues the 1897 model, but with the addition of a purpose:

For the advancement of knowledge and the dissemination and maintenance thereof by teaching and research there shall be a University to be called the Victoria University of Wellington..... The University shall be a body corporate with perpetual succession and a common seal, and may hold real and personal property, and sue and be sued, and do and suffer all that bodies corporate may do and suffer.

Salmond's view of the "thing" brought into existence by these legislative declarations was clear: ${ }^{32}$

31 Saleilles, above n 13, De La Personalité Juridique, 613, quoted in Fuller, Legal Fictions, above n 10

32 Salmond, Jurisprudence, above n 13, 7 ed, 84. 
The most important legal fiction recognised by modern law is that of incorporation - the fiction by which a body of individual persons, such as a trading company, a university, or the population of a city, is regarded by law as being in itself a person, distinct from the individuals of which that body is composed, and capable as such of owning property, making contracts, incurring obligations, and otherwise doing and suffering what real persons can do and suffer.

So what was wrong with this view - this "fiction theory" of corporate personality?

Plenty, thought some legal and political thinkers of Salmond's time and of our own. ${ }^{33}$

Primarily, these critics were suspicious of the fiction theory's insistence that whatever "personality" groups had was a concession by, and a creation of, the State. The clear implication of such a theory seemed to be that the State might make such concession limited, conditional and revocable in a way which it would not dare to do in respect of natural persons - in short, that the theory marginalised group or collective rights in favour of a duopoly on "real" identity involving at one end the individual, and at the other the State, with all else "unreal" and dependent upon the favour of the State. The modern critic might find that danger realised in Mrs Thatcher's dictum (and practice based thereon) that "there is no such thing as society, only individuals".

But, before we divide too quickly along these lines, consider that the reason the New Zealand Rugby Football Union was prevented by Court order from proceeding with its proposed tour of a racially segregated South Africa in 1981 was that it was an incorporated society and so constrained by the purpose which it was required to identify and register under the Incorporated Societies Act 1908 - in its case the fostering and encouragement of the game of rugby. The Court was thus able to find that the divisions in New Zealand society which the tour would produce meant that the NZRFU would be exceeding its powers in proceeding. ${ }^{34}$ Individuals could tour, but the artificial person of the Rugby Union could not - classic "fiction theory" stuff! Indeed, Salmond had drafted the Incorporated Societies Bill, and stated in the accompanying explanatory memorandum that: 35

The present Bill is an attempt to make adequate provision for the incorporation, management,

control, and dissolution of the societies to which it relates.

33 I discuss the views of the critics, principally Maitland, Figgis, and Harold Laski in Salmond: Southern Jurist, above n 8, 68-71. Laski is particularly severe in letters to Holmes.

34 I refer here to Finnigan $v$ NZRFU [1985] 2 NZLR 181, see Salmond: Southern Jurist above n 8, 90 at n 38. Technically, the finding was that the conclusion was sufficiently arguable to sustain an interim order.

35 The memorandum is found in Parliamentary Counsel Office, Bill Book 1908, 4/1. 
If I may return to our Victoria College and the nature of its "personality", I would observe that I could decide one day to burn all my books - and I will have a perfect right to do so. But Victoria University may not decide to burn its books - to do so would not be for the "advancement of knowledge" and therefore not in accordance with the statutory condition of its legal personality. Is this conclusion quite so monstrous a denial of the "group right" as Laski suggests?

The State controls - but also encourages and empowers - groups in all sorts of ways. Whether we say that the legal personality of such groups is "real", or a "fiction", does not seem to assist very much with the policy choices. In fact, Sir John Salmond may be given the last word: ${ }^{36}$

A group or society of men is a very real thing, but it is only a fictitious person.

The semantic basis of the argument is well shown in New Zealand by the debate about legal recognition of Maori tribes or iwi. The Runanga Iwi Act 1990 declared that:

The iwi is hereby acknowledged as an enduring, traditional, and significant form of social,

political, and economic organisation by Maori.

The Act went on to provide a process by which runanga (tribal councils) could, if tribal members so desired, be established, together with a "Charter", agreed by the tribe, setting out "the principles by which the runanga will be guided in the conduct of its affairs". The runanga could then be incorporated, and would have "all the rights, powers and privileges of a natural person", and was to be recognised by the Crown and all public autuhorities as "the authorised voice of the iwi". 37

The Act was short-lived, repealed with the change of government in $1990 .{ }^{38}$ The ostensible reason for its repeal was that iwi were autonomous and were not to have their identities dependent upon government recognition. It will be seen that this is a variant of the "realist" theory - iwi identity exists independently of the state. Indeed it does - as Salmond would say, the tribe is a very real thing - but to the question whether the tribe has "personality", the answer must be that it has "iwiality", and the trouble is that "iwiality" does not answer such questions as: can iwi sue? can iwi be sued? can iwi own property separately from the members? can iwi be taxed on income from commercial activities? How to choose between rival claims to represent iwi? Statutory incorporation and the creation of legal personality - as was proposed in the 1990 Act - could answer

37 Runanga Iwi Act 1990. 
those questions, the only issue being whether there are good reasons for allowing it to do so.

\section{A CONCLUSION}

Fictions can afford to lose contact with facts - although we must keep an eye out for elephants! Indeed, as we have seen, that is their very purpose - but they cannot afford to lose contact with purpose. It is purpose which keeps the fiction honest, and the relationship between fiction and purpose is as important as that between hypothesis and fact. When the goal is reached, or the purpose exhausted, it is time to consider whether the fiction should be dismantled like the scaffolding of a completed building.

Even Sir John Salmond's unbuttoned views on fundamental beliefs reflect the provisional and instrumental approach we have seen to characterise the use of fictions.

In his collection of aphorisms published privately in 1920 appears the following: ${ }^{39}$

Since all our beliefs as to the nature of the universe are probably mere illusions, there is much to be said in favour of accepting any creed that makes us happier than we should be without it.

39 John Salmond, 'My Son' said the Philosopher; being the Meditations of the Late Epaphroditus McTavish. 
